\title{
De momentos e alegrorias políticas: a Babilônia de Griffith e a dos Taviani
}

On monuments and political allogories: the Griffith and the
Taviani's allegories

\author{
ISMAIL XAVIER \\ Professor asssociado da Universidade de São Paulo \\ e coordenador do grupo de professores do CRT \\ do Centro de Estudos da Metrópole. \\ E-mail: ismail@pq.cnpq.br
}

\section{Resumo}

Este texto aborda a relação alegórica entre o cinema, aarquitetura, a religião, a art, a família, a Europa, os Estados Unidos, apartir dos filmes Bom Dia, Babilônia, dos irmãos Taviani e Intolerâcia, de Griffith. 0 confronto se dá, solene, alternando planos abertos que não nos diexam esquecer seu lugar - o cenário de Intolerância - e planos mais fechados que exainam as feições, imagens em que as duas figuras paternas confirmam sua história e o que delas podemos esperar.

Palavras-chave: cinema, Babilônia, alegorias, Griffith, Tavianis.

\section{0 banquete}

Estamos instalados no célebre cenário das escadarias da Babilônia, com suas colunas de elefantes e a monumental decoração que as fotos do filme Intolerância costumam exibir. Na sucessão de imagens que acompanhamos, quase sempre, este cenário é observado de um ponto de vista frontal, como já ocorrera no filme de 1916. Na parte baixa da arquitetura simulada, neste piso em que se acotovelavam os extras contratados pela superprodução, e moças dançavam em homenagem à deusa do amor, há agora uma certa rarefação. Outros atores se movimentam para compor uma outra cena, filmada em 1986, episódio de um filme moderno que remonta à vida de dois imigrantes italianos que, tendo se envolvido na realização daquele clássico do cinema, lá estão a preparar a mesa de um banquete nupcial, festa que sintomaticamente escolheu este lugar para transcorrer. Trata-se, desta forma, de um cerimonial; o que requer tal arquitetura, mesmo que de mentira.

Espectadores de Bom dia Babilônia, dos Irmãos Taviani, podemos aceitar o dado de monumentalização contido na construção de estuque e madeira, pois foi enquanto tal que ela ganhou celebridade como imagem. Tal consciência ajuda a projetar sobre a cena uma solenidade desejada pela própria mise-en-scène dos cineastas italianos que, como veremos, vão tomar este momento de sua narrativa para explicitar conceitos já sugeridos ao longo do percurso de seus personagens imigrantes, Nicola e Andrea, que lá estão, na California, a fazer sucesso como criadores (isto é fundamental, pois, embora pobres, eles não são meros funcionários da indústria). 
Há um padrinho nesta festa: o patrão dos jovens, o cineasta D.W.Griffith, figura já vista ao longo do filme, em diversas ocasiões, a atuar, com nítido senso de teatro, para compor a imagem de cavalheiro, mesclando uma certa canastrice e uma disposição efetiva a gestos de compreensão e bom humor, exibindo sempre uma atitude de nobre reconhecimento de valores e rivalidades. Já o observamos a exaltar o valor de Cabíria, o filme realizado por Giovanni Pastrone, em 1914; os Irmãos Taviani nos mostraram a forma como Griffith transformou o seu sentimento de ser ultrapassado pelo italiano numa forte inspiração para conceber o maior dos espetáculos, este que se prepara no cenário que ora as bodas de seus auxiliares vem emprestar. Quanto aos imigrantes, ele os ajudou a sair da penúria, defendendo-os, inclusive, de sabotagens quando necessário, pois foi sensível ao talento dos jovens que tiveram de abandonar a Itália quando o pai, mestre de obras restaurador de catedrais, orgulhoso de seu ofício, fechou a sua empresa por força de uma crise econômica.

Há um encontro marcado neste cenário. Pela primeira vez, o velho pai-patrão dá aos filhos a honra de sua visita, trazendo seu orgulho e também o ciúme da Itália. Não vem apenas como pai, mas como o representante de uma honorata tradição. Como artista voltado para a preservação do patrimônio europeu, ele vem exibir, na Califórnia e no coração do novo ofício das artes, sua estampa de patriarca, suas maneiras, sua autoridade que, bem sabe, precisa teatralizar para não perder a aura diante dos filhos. Marco de uma integração bem sucedida no novo mundo, esta cena encontra seu eixo dramático na aflição dos jovens diante do confronto entre o velho e o novo pai simbólico, diante desta emulação inevitável que ambos reconhecem e, para que tudo se dê bem, precisa se resolver na mútua aceitação dos valores que ambos personificam.

Trata-se, portanto, de uma cena alegórica. Estão aí envolvidos, o cinema, a arquitetura, a religião, a arte, a família, a Europa, os Estados Unidos. O confronto se dá, solene, alternando planos abertos que não nos deixam esquecer seu lugar - o cenário de Intolerância - e planos mais fechados que examinam as feições, imagens em que as duas figuras paternas confirmam sua história e o que delas podemos esperar. Os gestos e as falas são estudados, compondo um teatro consciente de quem sabe ser aquilo um duelo e, ao mesmo tempo, um movimento cujo destino deve ser a confraternização. O intervalo de aflições, embora não se alongue, é sofrido na pele dos jovens inseguros e suas noivinhas cujo drama nos diverte. Fomos preparados pelos Taviani a admirar o senso de performance de Griffith, e sua boa disposição para com os italianos. Ele não decepciona e, no momento chave, desafiado pelo torneio retórico de um pai disposto a colocar o novo mundo à prova, faz o elogio do cinema na figura da continuidade com o passado. Homenageia o pai e suas catedrais, explicando que o cinema é a nova versão de tudo aquilo que nos encanta na história da arte. Seu discurso satisfaz aos convivas, pacifica o pai e faz do próprio Griffith o porta-voz de uma idéia central de Bom dia Babilônia. A forma como esta idéia se expõe guardará sempre uma ambivalência (sobre isto, comentarei adiante) contida neste senso de teatro do cineasta americano, o qual projeta sobre seu enunciado uma dimensão retórica, tipo "imagem para exportação", discurso legitimador 
que, assumido por ele aqui e depois pela futura indústria e sua pomposa Academia, não seria propriamente para se levar a sério até o fim. De qualquer modo, no contexto de Bom dia Babilônia, os movimentos de ironia mais decisivos não estão propriamente dirigidos a Griffith mas à própria história da Europa nas vésperas da Primeira Guerra Mundial.

Em sua reflexão sobre o cinema no início do século, os Irmãos Taviani aliam a vontade de homenagear os que tiveram papel fundamental no nascimento da nova arte a uma preocupação de cunho nacional que termina por estabelecer paralelos interessantes entre o momento da realização de seu filme, tingido de certa melancolia não surpreendente nos anos 1980, e o passado que é objeto de sua representação, tempo em que, segundo eles, era ainda possível viver uma experiência de caráter épico, inaugural, heróico, digna de elogio.

Existe, na fala de Griffith, uma observação histórica que, se não resulta numa teoria do cinema, pelo menos alinha os Taviani com uma tendência da crítica de arte que, desde os anos 20, comparou o estatuto do cinema neste século com o das catedrais na Idade Média ${ }^{1}$. Filme e igreja seriam obras coletivas, reunião enorme de recursos, expressão dos valores da comunidade, núcleo de um ritual partilhado por todos, monumento que testemunha o poder criativo dos homens de uma época diante da posteridade. Encantado pela força social do cinema e sua dimensão de espetáculo visual dirigido a multidões, o historiador da arte Élie Faure, nos anos 20, fez esta aproximação capaz de, ao mesmo tempo, legitimar o cinema - ao inseri-lo numa tradição nobre - e imprimir uma feição mais plástica, visual, à nova arte num momento em que a prática favorecia $a$ atenção maior à narrativa ${ }^{2}$. Em adendo, oferecia aos cineastas algo que lhes interessava: a afirmação de sua dignidade expressa na função social elevada atribuída ao cinema que, como as catedrais, seria um lugar de celebração dos valores maiores do tempo, e não simplesmente uma diversão sob suspeita.

Convencidos desta dignidade, sempre empenhados na realização de um cinema de altos valores, com densidade estética, democratas de verdade e preocupados com a dimensão coletiva de seu trabalho, os Taviani fizeram, curiosamente, seu compromisso político e social encontrar expressão nesses conteúdos aqui arrolados na figura de D. W. Griffith. Embora haja a dose de ironia a que aludi, o conjunto do filme termina por construir a imagem de um herói com a qual o cineasta americano talvez sonhara, pois valores positivos nele se concentram para que ele possa assumir o papel de uma alegoria do cinema, personificando uma versão épica de sua emergência, consagrando-se, de novo, como o pai da nova arte com títulos de nobreza.

Em Bom dia Babilônia, tratase de uma discussão sobre a arte que, em função da vontade de elogio, transforma o passado em monumento. A conexão entre cinema e arquitetura serve de mediação para que se desenhe a idéia da continuidade do trabalho criativo cuja presença na história se cristaliza em edificações cujas magnitude e beleza testemunham o esforço da cultura em ganhar inteireza, superar a ação corrosiva do tempo, ainda que em meio a catástrofes e guerras. Nesta visada dos Taviani, vale a atenção ao que denota perfeição, põe-se como obra inteira à disposição do olhar. Embora seja democrático o
${ }^{1}$ No início do filme, o pai mestreartesão, em pleno canteiro de obras, senta-se numa cadeira que lembra muito bem a célebre cadeirinha do cineasta, e o final da restauração da catedral que marca a primeira sequência se desenha como observação de um espetáculo: um imenso pano cobre a fachada da igreja como se fosse uma cortina, e todos ficam imóveis à espera da remoção desta cobertura para que tal fachada possa se dar como espetáculo a eles e a nós. Fica desde cedo antecipada a identidade, sob os auspícios da arte, entre o velho pai e o diretor de Intolerância.

${ }^{2}$ Ver a antologia de textos de Élie Faure sobre cinema, reunidos no volume Fonctions du cinéma (Paris, Plon, 1953). 
horizonte, insinua-se uma concepção de arte muito cerimonial. Catedral ou superprodução cinematográfica, o que representa o feito artístico no filme são os picos monumentais, onde uma época consegue oferecer à história a auto-imagem desejada ${ }^{3}$. Sem dúvida, há o percurso dos jovens artesãos em tarefas simples, há o destaque para os inúmeros trabalhadores anônimos de Los Angeles que atestam um mundo da arte mais cotidiano, sem pompa. Mas tudo não chegaria a termo não fossem as obras maiores, as que "ficam" porque se credenciaram aos cuidados das gerações futuras para quem elas serão patrimônio. $\mathrm{O}$ esforço nesta direção é tal que o elogio da arte do cinema precisa idealizar a figura de Griffith, projetála numa esfera cavalheiresca em que seu poder se confunde com a autoridade do pai, agora justo e bonachão, que supera qualquer mácula e corrige os golpes baixos e a violência presentes no mundo à sua volta. Sim, porque o médio escalão, na empresa e na família, é o foco das agressões, dos ódios recíprocos. A inveja já estava lá na sequência inicial em frente à catedral recém restaurada, em contraste com a candura e inocência dos dois jovens "mais inspirados", talentosos e, por isto mesmo, destinados a trazer a contribuição italiana para a grandeza de Intolerância. E se repete em Hollywood quando os jovens concebem e executam os elefantes do cenário do filme, apoiados num saber e num repertório figurativo que resultam diretamente de seu antigo trabalho de esculpir os detalhes das decorações de catedrais.

No encontro de Griffith com tal

${ }^{3}$ Utilizo aqui a oposição documento/monumento tal como posta por Jacques Le Goff em seu livro História e Memória (Campinas, Editora da UNICAMP, 1994). imagem que preside o início e o fim: tal imagem está lá esculpida na catedral onde trabalha a família italiana logo na abertura do filme, no cenário de Cabíria que tanto desafia Griffith, no trabalho dos protagonistas que tanto sastisfaz o diretor de Intolerância e, finalmente, na evocação que encerra Bom dia Babilonia. Tal evocação nos traz de volta à sequência e à catedral do início, com destaque para a imagem esculpida dos elefantes, imagem que vem celebrar, pela última vez, a permanência da criatividade na história em meio a sofrimento e desastre. Sem dúvida, há traços de melancolia nessa imagem final que repõe a do início; ela faz retornar, em sua plenitude, o monumento e o trabalho de restauro exatamente quando a emoção do espectador está voltada para a assimilação da morte dos protagonistas que voltaram à Europa para selar seu destino na Primeira Guerra Mundial. Há diversas formas de entender a alegoria final, construída pela montagem que vem opor o trabalho de restauro e o brilho do monumento ao cenário de guerra, morte e destruição que sela o destino dos protagonistas. Mas o que me interessa ressaltar é o que aí prevalece de afirmação dessa continuidade, não da ruptura, o que aí se afirma de celebração de uma inteireza sobreposta ao cenário de ruínas. Se o momento final da diegese exibe a Europa como palco de guerra, paisagem entrecortada de fumaça, explosões e cadáveres, o velho continente ainda encontra seu emblema na peça de patrimônio histórico que compõe o pano de fundo da cena em que morrem Andrea e Nicola. Se estão todos lá a padecer o desastre da guerra, o lance da montagem retira arquitetura e personagens das vicissitudes do tempo, para tomá-las como figuras 
símbolo de uma permanência que, de resto, foi de diversos modos evocada ao longo do filme. Os jovens italianos morrem, por coincidência (ou por alegoria) juntos num campo de batalha observado pelo monumento, tal como se estivessem num melodrama bem ao estilo de Griffith; e lá está a câmara de cinema que eles terminam por usar na produção de seus retratos - um filma o rosto do outro - endereçados aos filhos recém nascidos que quase não conheceram.

Há, nesta sequência final, a presença da câmara nas operações de guerra, numa referência à função documentadora - para efeitos militares, jornalísticos e de propaganda - que a nova técnica teve naquela conjuntura. No entanto, seria abusivo associar esta presença com o debate gerado pelo livro de Paul Virilio, Guerre et cinéma, pois os Irmãos Taviani não estão empenhados em marcar a conexão entre o cinema e a nova "logística da percepção militar", nem há lugar no filme para considerações sobre fotografia aérea, vôos destinados a mapear o teatro das operações, enfim os lances que definem a guerra também como um conflito de percepções, de capacidades de gerar informação e pontos de vista ${ }^{4}$. A câmara ali tem um ar de peça artesanal, feita à medida do soldado de infantaria que registra a experiência numa escala mais reduzida, e também à medida do gesto de Andrea e Nicola que resolvem fazer um uso privado do dispositivo. Seu lance final de produção de imagem tem a conotação do álbum de família, peça de recordação do pai pautada pelo sorriso que os dois se forçam a compor como mensagem de inteireza, legado de vida, na iminência da morte. Tal ritual repõe a questão da memória em chave doméstica, e sua ressonância simbólica supõe a mesma tônica da imagem-monumento que domina o filme, embora em ponto menor.

Definida esta tônica da imagemmonumento e a afirmação de um horizonte de continuidade mesmo diante dos desastres da história, gostaria de comentar dois aspectos da passagem Europa-Estados Unidos em Bom dia Babilônia.

\section{Chuva de pedras no palácio de cristal}

Num primeiro aspecto, há a passagem de um saber milenar que, através dos italianos, se incorpora ao cinema. Griffith é tomado como o grande mestre, os Estados Unidos como o berço maior da cultura de massa tal como a conhecemos, mas foi preciso a inspiração vinda de Cabíria. Foi preciso que a atenção dos americanos se voltasse para a maestria dos italianos e seu pavilhão espetacular na Exposição Internacional de 1915 em San Francisco, lugar da sessão de cinema que projetou o filme de Pastrone para o diretor de Intolerância. E foi preciso que dois jovens que trabalharam no pavilhão italiano fossem parar em Hollywood para que a obra de Griffith atingisse seu patamar maior. Há, neste enredo, a incorporação de muitos dados interessantes da Belle Époque que os historiadores têm estudado em conexão com o desenvolvimento do cinema: a importância das feiras internacionais em que os diferentes países exibiam seu grau de desenvolvimento, competiam em estilo nobre na esfera do espetáculo arquitetônico e da tecnologia de ponta para reafirmar, amigavelmente, uma concorrência que tinha seu lado mais sinistro e que desembocou na Primeira Guerra Mundial. Estava celebrada nestas feiras uma nova
${ }^{4}$ Ver Paul Virilio, Guerre et cinéma (Paris, Cahiers du cinéma-Editions de L'Etoile, 1984). 
${ }^{5}$ Nota do autor feita em 2008: a história recente das Olimpíadas, que vem culminar no espetáculo dos Jogos Olímpicos da China, mostra muito bem como a trans-formação dos certames esportivos em espetáculo de TV colocou os variados jogos internacionais, notadamente as Olimpíadas, no mesmo diapasão de uma monumental afirmação nacionalista embalada no discurso de confraternização entre os povos. Enfim, em outros termos e em outra conjuntura internacional, a história das alegorias como monumentos nacionais continua, turbinada pelo esporte. noção de espetáculo aliada à idéia de progresso que, afinal, inseriu o cinema e definiu os parâmetros da primeira forma de assistência e de observação do mundo da tela na virada do século. Mas estava celebrada aí também a importância do nacionalismo como força política a exacerbar competições naquilo que Eric Hobsbawm denominou a Era dos Impérios, momento imediatamente anterior à Guerra, início da decadência do poder colonial europeu, correlato à emergência dos Estados Unidos e à consolidação do cinema como mercadoria internacional apta a circular em redes já organizadas, para um proveito que a guerra destinou aos americanos ${ }^{5}$.

$O$ dado significativo nesta orquestração de fatos é que o filme, ao celebrar Griffith e Hollywood (esta observada em sua fase incipiente como se fosse uma pequena comunidade), destaca acima de tudo o papel dos italianos naquele momento chave, num toque de celebração nacional que permanece em sua força, mesmo que, no final, a morte dos artesãos se inscreva num tratamento alegórico da derrocada européia responsável pelo que há de melancólico no filme. Este é o segundo aspecto da passagem posta pela fábula dos Taviani: o da questão nacional no momento em que ela se explicita como foco de violência, não como concerto de criatividades. Face a ela, cabe primeiro observar como os Taviani trabalham o problema da rivalidade numa chave mítica e, em seguida, comentar a forma como posicionam o cinema diante da carnificina do século.

Os jovens italianos trazem no corpo cicatrizes que provocam, em suas namoradas americanas, indagações cuja resposta vem ilustrar o valor da profecia do pai, quando este os abençoou, não sem certa amargura, no momento em que partiram para a América. Ele dissera: permaneçam juntos, pois está aí a vossa força; separados, sucumbirão. A palavra do pai ressoa quando, numa cena na relva hollywoodiana, ambos comentam com as namoradas a violenta briga em que se envolveram quando crianças, momento de espanto diante da própria violência e da sua possibilidade de tomar o próprio irmão como alvo. $O$ final da estória é a concretização desta profecia. No auge do sucesso ambos se casam. E a cena da festa em pleno cenário de Intolerância é seguida pela sessão de gala em que Griffith apresenta a sua obra e sela sua cumplicidade com os italianos. Mas o final da projeção reserva a trágica surpresa, fazendo irromper na tela a questão da entrada dos Estados Unidos na grande guerra européia, antes uma notícia de jornal sem destaque no filme. Tudo se precipita. $\mathrm{O}$ tumulto gera a crise nervosa que afeta a gravidez das duas jovens que têm de ser levadas às pressas para o hospital, onde nascem os dois bebês e uma das mães morre, deixando Nicola viúvo. Este não assimila com maturidade o golpe, voltando-se contra o irmão, lidando muito mal com a ajuda que passa a receber e, por fim, coroando sua auto-destruição no alistamento militar que o leva à guerra. Separados, enfim, os irmãos fracassam, tudo dá errado, culminando com a tentativa de Andrea em encontrar Nicola em plena guerra, ensejando o desfecho desafortunado.

Não é pequena a dose de melodrama na última parte do filme. Como observei, tudo se passa como se houvesse esta vontade de fazer um desfecho à Griffith, inverossímil, com personagens definindo um comportamento forçado que não parece fundamentado em nada que 
não seja o cumprimento da profecia do pai. Esta, por sua vez, define o paradigma da paz e da guerra, opondo a união fraterna, que gera paz e sucesso, à separação, rivalidade, ressentimento, que geram a guerra. Ou seja, há um jogo de espelhos pelo qual o destino dos irmãos reflete o destino imediato da Europa, e fornece um modo de pensá-lo na chave melodramática da família. $\mathrm{O}$ que termina por dispensar o filme de qualquer consideração efetiva sobre a guerra que, afinal, irrompe abruptamente como uma tempestade no filme, reforçando o contraste com o tom pastoral da vida em Hollywood, tal como reconstituída no filme. A guerra se afigura como invasão, mal que vem do exterior e marca sua alteridade face ao mundo das personagens; uma vez ela presente, há um curioso enterro de tudo o que representava realização, cultura em movimento. Griffith desaparece, os estúdios com ele. E o cinema só volta a aparecer na figura da câmara abandonada por um cinegrafista morto no cenário de guerra, para ser usada pelos irmãos em seu último gesto. Fica selada a descontinuidade entre a visão elegíaca da então pequena cidade dos construtores da nova arte e a visão dantesca da guerra, como sugestão de uma distância radical entre uma e outra.

Bom dia Babilônia é simpático à feição nacional dos processos quando se trata de afirmar a contribuição italiana ao nascimento do espetáculo cinematográfico. Mas se vê separado daquele momento épico, alvo do seu elogio, pelo corte abrupto simbolizado pela guerra, foco de um comentário sobre a crise européia feito no momento dos diagnósticos sombrios endereçados a um cinema por hipótese agonizante diante das novas tecnologias do entretenimento, momento de um declínio contundente do cinema italiano, emperrado na produção e com seus cineastas repondo o dilema de "filmar ou não filmar" em Hollywood, espécie de sonho ou pesadelo migratório que se cristaliza na fábula dos irmãos Andrea e Nicola (em nítido espelhamento com as questões enfrentadas pelos próprios Irmãos Taviani). Nesse momento de crise do próprio cinema, e de crise de produção na Itália, a homenagem aos primórdios se alia à melancolia gerada por tal sentimento de viver a idade da decadência. $\mathrm{E} o$ que é particular no gesto dos cineastas, é este alçar vôo em direção ao modelo da arte enquanto arquitetura, monumento, vôo que permitiu uma operação, talvez não bem sucedida, de sublimar os conflitos na afirmação de um princípio de continuidade da criação ao longo da história, qualquer que sejam as vicissitudes da experiência vivida. O preço pago por Bom dia Babilônia, ao deslanchar esta operação, é a forte idealização da produção artística, presente na imagem cavalheiresca do cineastapai que se monumentaliza em paralelo às edificações celebradas ao longo do filme. Separa-se o mundo dos artistas - onde se destaca um D.W.Griffith pacifista - e o mundo dos valores que geram a guerra.

Essa sublimação da história concreta se efetiva também na aproximação, em abstrato, entre produção cinematográfica e corporação de ofício nos moldes medievais, implícita no espelhamento entre cinema e catedrais, implícita na identidade dos dois pais-patrões, trabalhados no filme como se fossem sacerdotes de uma religião da arte entendida como momento exclusivo de beleza e de esperança face a um mundo de desastres diante do qual os artistas só podem proclamar a sua alteridade.

Gostaria de explorar aqui este 
dado de monumentalização que se manifesta de modo pleno na observação do objeto de arte, porém mais timidamente quando se insinua no elogio ao momento épico do espírito nacional diante do cinema, uma vez que o filme se fez numa conjuntura pouca afeita à euforia e à exaltação nacionais, atitudes que, de resto, não seria próprio aos Taviani encarnar, representantes que sempre foram de um cinema político mais disposto à análise crítica do que à mitificação. $\mathrm{O}$ que me intriga neste filme é o fato de que sua alegoria do cinema-arte, não sendo nem se querendo ela própria um monumento nacional, opere com sublimações que idealizam exatamente aquilo que sempre esteve comprometido com tudo o que o filme lamenta em sua melancólica referência à guerra e à crise européia.

Neste sentido, as tensões entre a idéia da história como construção e teleologia e a idéia da história como violência e desastre não são trabalhadas na chave sugerida por Walter Benjamin, em que uma coisa está implicada na outra, dependendo do ângulo de observação. Há no filme uma tendência a resolver a melancolia numa chave oposta, separando os documentos de civilização dos documentos de barbárie, resguardando o que Marcuse cunhou como o "caráter afirmativo da cultura", espécie de reduto dos valores sem vigência efetiva na prática. Em outras palavras, é a separação entre a arte, como instituição, e a esfera dos conflitos reais que constitui o solo desta monumentalização presente em Bom Dia Babilônia, a qual se projeta sobre a figura de Griffith.

Embora a fala do cineasta no banquete acentue este aspecto de seu ofício, entendido como fiel a um legado construtivo da história, o seu senso de teatro gera ambiguidades que restam pouco exploradas, dada a opção pelo melodrama na última parte do filme. Tal opção desloca as tensões para o polo familiar da estória, tomado como ressonância de um desastre que tem o solo europeu como origem, preservada então uma "inocência" da província de Hollywood que resulta curiosa quando se contrapõe com a maneira contundente com que os filmes americanos, incluído Intolerância, compõem a outra face da mesma moeda nacionalista, competitiva e agressiva, presente na ideologia de ordem e progresso que se consolidou, do lado de cá do Atlântico, entre a guerra civil americana e a primeira guerra mundial.

Tomando o filme dos Taviani como referência, cabe operar aqui uma reversão de ponto de vista de modo a qualificar esse olhar europeu que insiste em só destacar, do projeto Intolerância, o que o credencia como um monumento à arte do cinema, muitas vezes idealizado como o canto de cisne de uma suposta idade da inocência antes da hegemonia do grande capital na produção americana. Observemos as imagens de Griffith para repor, através delas, como se define uma auto-imagem nacional apta a celebrar uma vocação do cinema e do próprio país no seio da história. Emerge destas imagens uma cumplicidade entre cinema e nacionalismo norte-americano que terá desdobramentos na história de Hollywood, embora as mudanças de situação prática e clima ideológico não mais propiciem a repetição pura e simples do que se pode ver, por exemplo em um filme como $O$ Nascimento de uma nação.

\section{A nação e a guerra segundo o princípio melodramático de exclusão}

O nascimento de uma nação 
não é primeira alegoria nacional na história do cinema, mas é, sem dúvida, o primeiro grande impacto, em escala nacional, que um filme político voltado para a narração de um episódio da história alcançou, despertando polêmicas, animando a $\mathrm{Ku}$ Klux Klan, sofrendo a ação da censura em alguns estados da federação e alterando completamente os parâmetros do espetáculo cinematográfico, na envergadura da sessão de cinema, no perfil de classe das platéias e no dinheiro arrecadado. Os americanos se convenceram, de vez, que o cinema poderia ser uma enorme fonte de lucro, e também uma potente arma ideológica, com as sabidas consequências para a história do cinema e para a história do racismo nos Estados Unidos.

Para seu impacto, contribuíram a natureza do episódio focalizado - a Guerra Civil, entendida como o momento em que a nação se constitui enquanto tal - e a posição conservadora de Griffith, cuja versão da história transformava os escravos africanos na semente de todos os males implantada erroneamente na América. Para ele, a nação que nasce por volta de 1865 é feita de brancos vindos da Europa, homens e mulheres que podem invocar a ancestralidade do sangue sagrado que se derramou em terras da Escócia. O mais são presenças alheias ao corpo da nação. Esta, após o trauma da guerra, só pode se constituir na medida em que assumiu, graças à ação heróica de sulinos virtuosos, o princípio de que a paz social e a prosperidade dependia da exclusão dos bárbaros portadores da semente envenenada e, portanto, de uma concepção dos direitos civis como patrimônio exclusivo dos brancos civilizadores da nova terra, de resto, entendida como um deserto desabitado à espera da fertilização européia.

Para o impacto do filme, contribuiu também a dimensão monumental da alegoria, a grandeza do espetáculo, a capacidade de imposição das imagens, os acordes heróicos da orquestra na sala, em suma a sua condição de exemplo decisivo de que a intensidade era algo que importava muito no cinema, requerendo para tanto o investimento necessário. No entanto, isto tudo não teria o efeito que conhecemos não fora a maestria do cineasta no plano da dramaturgia, tanto na elaboração da estrutura geral de sua estória quanto na composição de cada cena, tarefas para as quais se adestrou durante anos na confecção de centenas de filmes de curta duração onde foi gradualmente promovendo a otimização dos recursos técnicos do cinema em favor da exposição clara das linhas de ação e dos conflitos, da legibilidade dos sentimentos num rosto, da expressividade dos gestos, da separação clara de Bem e Mal. Em suma, em favor do melodrama.

$O$ nascimento de uma nação é uma narrativa de fundação nacional ${ }^{6}$ que equipara o destino da nação ao destino de um par amoroso em que herói e heroína pertencem, em princípio, a mundos aparentados mas tornados opostos e em estado de guerra "por culpa dos negros". O caminho da consolidação nacional passa pelo sofrimento, em que familiares de herói e heroína se sacrificam. Moços morrem na guerra fratricida e a virgem branca, ameaçada por um negro, morre em nome da pureza e da honra para inspirar a reação do herói, sua vingança legítima porque reparadora do Bem. E a história da união nacional passa por tais episódios canônicos onde se desenha a história das duas famíllias, uma do Sul, outra do Norte, cuja união final é o ajuste
${ }^{6}$ Ver Doris Sommer, Foundational Fictions: the National Romances of Latin America (Berkeley, University of Califórnia Press, 1993). 
simbólico da própria sociedade nas bases certas. Isto faz sentido na estrutura do filme porque, nele, o princípio de sociabilidade matriz é o da família, e os termos em que se discute a experiência nacional só podem derivar da lógica interna e dos valores da família, onde homens e mulheres seguem as regras tradicionais ditadas pela função paterna, centro do poder e da projeção familiar na esfera pública, e assumidas pela função materna, centro da ação nutriz e confinada ao espaço da domesticidade pelo qual deve zelar. O fundamental nesta estrutura é a obediência a um princípio de exclusão: há uma pureza a ser preservada, e o diferente (entenda-se impureza) deve ser mantido à distância, fora do espaço doméstico (território nacional), onde a mãe virtuosa e a filha virgem são as figuras depositárias da tradição de sangue que não pode ser manchada. Daí porque a história é um grande melodrama, feito de inocências carentes de proteção e de heróis que se engrandecem ao cumprir tal tarefa diante de ameaças inevitáveis, pois o mundo não é homogêneo. Se a raiz do mal está na diversidade $\mathrm{e}$ nas aberturas de um mundo que não se põe mais como um feudo confinado da Idade Média, é preciso refazer o mundo naqueles moldes antigos, colocando no topo a ordem dos cavalheiros, com os quais podese dizer que, ressalvadas todas as mediações de quem tinha os pés no concreto, Griffith se identificava, pois as polaridades de sua visão moral tornavam tal figura um tipo ideal que, pelo menos nas maneiras, um adulto do século vinte podia imitar, com algumas adaptações.

O que observo aqui sugere um cotejo irônico com o tom cavalheiresco do democrático e pacifista monumento do cinema desenhado pelos Taviani. Sem dúvida, descrever o racismo de $O$ nascimento, e a belicosidade inerente ao etnocentrismo de origem européia aí presente, é um caminho fácil de desautorização do Griffith ideal que observamos a realizar Intolerância em Bom dia Babilonia. Estaria eu aqui esquecendo uma questão de princípio, ao não levar em conta o que hoje se sabe sobre a não identidade entre a pessoa e a figura de autor que emana de uma obra de ficção. E esquecendo uma questão de fato, pois a historiografia já pesquisou, e a documentação apontou, o quanto a realização de Intolerância tem a ver com um gesto de reparação pelo qual um cineasta, surpreso diante das acusações, quis mostrar a todos os seus críticos o quanto era simpático a certas causas sociais do presente, ou o quanto era capaz de fazer a elegia de um mundo alheio ao seu universo cristão e europeu, exatamente na figura do que na Bíblia é apanágio do pecado e da perdição humana: a Babilônia.

Para discutir melhor o problema que apontei, é preciso desenvolver o que, presente em $O$ nascimento, vai funcionar, a partir de Intolerância, como matriz subjacente para futuras produções de Hollywood, particularmente no caso do western e dos filmes de guerra, gêneros que se revelaram talvez os mais bem sucedidos no ajuste entre dramaturgia, iconografia e ideologia nacional. Quando observei a feição guerreira do princípio de exclusão do melodrama em que o Mal é o diferente e a pureza da linhagem é assumida como tabu nacional, parti de sua versão mais caricata, presente com todas as letras em $O$ nascimento. Na história do western como gênero, muito do que aí se dramatiza, com o negro fazendo o papel da figura da alteridade, se desloca para o indígena, dentro do 
mesmo princípio de civilização contra barbárie. No entanto, nos melhores exemplos do gênero, tal esquema se complica, adquire nuances que ganham espaço na medida em que outras modalidades de conflito, igualmente caros ao imaginário nacional, forçam a passagem para vir ao centro, resultando em obras mais complexas, tal como ocorre nos filmes de John Ford.

Vejamos como se articulam, em Intolerância (afinal, o núcleo de Bom dia Babilônia), as posturas do cinema americano no que tange à moral, à guerra e ao estatuto da nação na história. Desenha-se aí uma das referências maiores dessa teleologia do progresso que, nos Estados Unidos, se confundiu com a idéia do "sonho americano" na terra prometida. E desenha-se aí, em chave aparentemente pacifista. a matriz destas alegorias nacionais de hegemonia tão duradouras em Hollywood e no imaginário americano. Este é aqui observado em dois de seus aspectos mais problemáticos: o do poder patriarcal e o da supremacia da nação, com suas formas de defesa.

\section{A moral da história em Intolerância}

Sempre foi digna de nota a forma como Griffith se mostrou sensível, no episódio moderno de Intolerância, à luta de classes, tomando o partido dos trabalhadores em greve contra um capitalista explorador e autoritário que serve de baliza para que se evidencie a ligação entre economia e caridade cristã, produtividade industrial e vigilância moral dirigida aos operários. Jenkins, o capitalista, visita, à noite, o bairro operário para fazer a crítica do divertimento legítimo de seus funcionários, reivindicando a tutela dos corpos e do entretenimento para que, nas horas de trabalho, todos possam alcançar melhor rendimento. Em sua mansão, o baile noturno é ocasião para que sua irmã solteirona apresente seus projetos filantrópicos, aliados a outras formas de exercer a mesma vigilância sobre o estilo de vida dos pobres. As iniciativas de assistência social pretendidas exigem um dinheiro que Jenkins só consegue cortando o salário de seus operários.

Tal esquema denuncia os mecanismos da falsa caridade e transforma Jenkins num tipo eticamente condenável, o que dá uma retaguarda moral à reação dos operários, mas atrela o tema da greve à questão da intolerância das senhoras carolas que insistem em tutelar os costumes da população. Não por acaso, após a sequência catártica em que a greve encontra forte repressão e o confronto com a polícia gera várias mortes, a questão do trabalho industrial desaparece, e Jenkins com ela. Ficam em cena algumas vítimas da greve que são relegadas ao desemprego e migram para a cidade grande que, ao contrário do que nos ensina a história americana em torno de 1900 , não é propriamente o espaço da indústria (esta, neste filme, se localiza numa pequena cidade que tem até um clima pastoral no bairro operário). $\mathrm{O}$ problema das personagens se desloca para a questão do marginalismo urbano, a criminalidade. A migração repõe com toda força o eixo moral dos conflitos. Como se manter honesto no ambiente corrupto de um bairro "barra pesada" dominado por gangsters? As vicissitudes do herói desempregado nas ruas da cidade estarão todas entrelaças com a contravenção, o sexo, brigas de rua. A formação do casal protagonista começou lá nos tempos do trabalho na indústria quando flertavam à vista do pai da moça que também migrou para a cidade grande; mas é neste 
7 Ver Miriam Hansen, Babel and Babylon; Spectatorship in American Silent Film (Cambridge, Harvard University Press, 1991), e Michael Rogin, "The Great Mother Domesticated: Sexual Difference and Sexual Indifference in D.W.Griffith's Intolerance", in Critical Inquiry Spring 1989, vol. 15 number 3. ambiente corrompido da metrópole que os jovens terão de construir sua relação, a moça correndo perigo no assédio sexual dos chefes de gangue, o moço enfrentando a armadilha dos bandidos que o levam para a cadeia, acusado de um crime que não cometeu. Ao conflito entre capital e trabalho, que não desenvolve, o filme faz seguir e prevalecer o conflito moral centrado no sexo, nas ameaças à família, no erro judiciário, este último polo maior do suspense e da montagem paralela final.

Consolidando este privilégio conferido ao eixo moral, há o fato de Miss Jenkins, a irmã do industrial, estar na raiz de todos os dramas, definindo com clareza qual é o alvo do cineasta ao escolher o tema da intolerância para responder ao alvoroço causado pelo seu filme anterior. Ele demonstra aqui maior sensibilidade às questões sociais e ao pobre, num movimento que se coaduna com o que já estava presente em seus filmes da Biograph, onde tinha manifestado sua condenação aos capitalistas insensíveis, sempre dentro deste mesmo eixo moral. Ele pauta agora seu discurso por um chamado à flexibilidade, e algo além da acusação de racismo e das manifestações de censura a $O$ nascimento o preocupa. A diatribe contra tipos sociais como Miss Jenkins - a vilã da parte moderna de Intolerância dá a pista: os adversários de Griffith, em 1916, estão nos grupos empenhados na chamada Social Reform, gente que cobre um espectro que vai das senhoras religiosas que mobilizam exércitos em defesa da moral cristã a grupos progressistas mais voltados para o apoio à maior participação da mulher na vida social, no trabalho, na vida pública. Em particular, os adversários a que Griffith quer responder em 1916 são os defensores de uma modernização que inclua aspectos recalcados na teleologia do progresso e da hegemonia nacional que seus filmes tematizam e, em verdade, querem ser a sua própria encarnação. Os historiadores da cultura americana, notadamente Miriam Hansen e Michael Rogin, já analisaram esta questão e caracterizaram de forma documentada as razões que fizeram de Intolerância este monumento à Maternidade como instituição sagrada e centro da história ${ }^{7}$. Rogin aponta a oposição entre o controle da sexualidade feminina exigido pelo patriarcalismo exaltado nos filmes de Griffith e a presença de campanhas lideradas por liberais e feministas em favor da divulgação de formas de controle da natalidade como parte de um movimento de emancipação da mulher (que assumiria o controle da sua sexualidade) já esboçado em outras esferas da vida. Hansen acentua a relação entre esta idealização da maternidade e a necessidade de reforçar a ideologia vitoriana da domesticidade para se opor à chamada Progressive Era, quando mulheres foram massivamente integradas ao mundo do trabalho e lutavam por direitos, ameaçando estruturas familiares tradicionais, retirando a questão da maternidade de sua esfera metafísica e introduzindo, enfim, a questão do controle da natalidade.

Para expor sua posição diante do problema, Griffith estruturou sua retórica em duas frentes, na configuração do enredo e dos tipos sociais do episódio moderno, e na montagem da alegoria histórica feita de quatro episódios pontuados pela imagem-refrão de Lillian Gish balançando o berço, alegoria da maternidade.

$\mathrm{O}$ enredo que envolve Miss Jenkins e o casal de protagonistas se organiza em torno da função 
materna. Migrados para a cidade, os jovens alimentam seus projetos de vida em comum. O pai dela morre; eles se casam. A felicidade dura pouco. Ele é preso e o filho nasce para ser cuidado por uma mãe deixada só e sem recursos. As senhoras da reforma social comandadas por Miss Jenkins declaram a mãe incapaz e conseguem um mandato judicial para assumir a custódia do bebê. E Griffith não dispensa recursos para avivar o drama da mãe impotente de quem se usurpa o direito de exercer a sua vocação. As responsáveis por tal vilania são mulheres solteiras que o filme desenha como frustradas, carentes, ressentidas e talvez transgressoras da norma sexual (há sugestões de lesbianismo). Ou seja, mulheres que não atenderam à sua vocação maior, furtando-se ao papel sagrado do seu sexo na história - a maternidade e as prendas domésticas - e voltando-se, deste modo tão atrapalhado, para a vida pública. A raiz do mal está, portanto, nesta heresia, uma forma entre outras de mulheres desandarem - e a ordem social com elas - ao não cumprirem os códigos patriarcais tão claramente expostos lá em $O$ nascimento. Com tal esquema, o filme atinge o alvo, vilanizando os interessados nas reformas ao reduzilos à feição carola, assistencial, autoritária, intolerante do grupo liderado por Miss Jenkins.

A argumentação, no entanto, só se completa com a moldura geral da alegoria, onde o polo decisivo não é propriamente a imagem-refrão do rocking craddle que pontua boa parte das passagens de uma época histórica para outra, ajudando na composição dos paralelismos. O mais importante é a presença de uma teoria da história que se expressa na escolha dos quatros momentos focalizados, no teor das comparações possíveis que o desenvolvimento paralelo permite, na diferença que marca o desfecho de alívio e resolução do último episódio face ao tom trágico do que se vê em todas as outras épocas colocadas em foco. A dominância técnica do paralelismo e o fato de se definir um princípio único comum - a luta do espírito fraternal e do amor contra a intolerância - a comandar as ações em todas as épocas pode dar a impressão de que o filme só está empenhado em destacar repetições, a recorrência do mesmo conflito entre as forças do bem e do mal. Há, sem dúvida, este aspecto. E a significação de uma personagem como Miss Jenkins se define melhor quando lembramos que a montagem a associa diretamente aos fariseus do mundo antigo, à hipocrisia e intolerância religiosa dos inimigos de Cristo. A passagem é direta entre a figura da vilã moderna e a cena em Jerusalém que destaca tais sacerdotes de má vontade. Além disto, num outro cotejo permitido pela montagem, esta personagem feminina do século $X X$ apresenta o mesmo semblante, antipatia e maus desígnios que revelam o rosto e as caretas da atriz que interpreta Catarina de Medici no episódio da Noite de São Bartolomeu, na França do século XVI, em pleno ápice das guerras religiosas. A Rainha Mãe é o foco das intrigas, incita o ódio, conspira e comanda o massacre dos protestantes em Paris, fazendo de sua dedicação ao poder do Estado e à vida pública uma contrafação masculina que a faz trair a missão do seu sexo na Terra, projetando-a nas antípodas do ideal vitoriano da delicada e piedosa domesticidade feminina. Considerada a teleologia cristã de ordenação da história como desdobramento do Plano Divino de queda e salvação, há uma relação tipológica (Eric Auerbach diria 
"figural") que une os fariseus, Catarina e Miss Jenkins como figuras que se complementam na medida em que tal plano da história se desdobra. Esta é a dimensão mais ampla da ordem universal que situa e faz mais nítida a natureza de Miss Jenkins como personagem associado ao Mal, de modo a fundamentar o julgamento e a condenação que todo o processo narrativo constrói ao longo das várias horas de duração de Intolerância. Para além do quadro genérico de uma ética cristã e patriarcal, grosso modo reproduzida em milhares de filmes, o ponto nevrálgico da moral de Intolerância está aí neste enunciado polêmico, de alvo definido em 1916, que proclama a liberação das mulheres e sua invasão da esfera pública como traições ao mandato da mãe-doméstica, invasão que instaura a desordem e o Mal na sociedade.

É possível também se colocar a questão feminina em termos do dever da fertilidade, uma vez que as políticas de controle da natalidade e a diversificação dos papéis femininos na sociedade moderna podem ser origem de um desastre ainda maior na perspectiva ideológica de Griffith. Desde $O$ nascimento, ele deixou muito clara a sua condenação de casamentos inter-raciais e a necessidade de proteger a mulher branca. O desdobramento desta proteção à pureza, num mundo não homogêneo e com pressões demográficas, não pode ser outro senão a maternidade como um dever, a fertilidade como missão, em nome da hegemonia da raça. Esta é razão para que o filme tenha uma postura tão elegíaca ao mundo babilônico, tão favorável na representação de seus costumes e tão elogiável para suas conquistas como a escrita cuneiforme, o código de Hamurabi e todo um aparato arquitetônico que desfila na tela com insistência, em favor da ostentação da competência e riqueza do espetáculo. Os devotos de Ishtar, a deusa do amor e da fertilidade, podem expor a sensualidade de sua cultura (de resto, observada pelo cineasta dentro dos estereótipos do exotismo oriental). E podem ser o centro do que há de erotismo em Intolerância, empenhado em ressaltar a felicidade de uma vida cotidiana vivida na tônica do amor. Afastando-se da imagem construída na Bíblia, não condenando a Babilônia como núcleo do pecado e da perdição, o cineasta prefere o elogio porque, estrategicamente, é hora de defender o princípio que orienta o seu culto maior: o da fertilidade. $\mathrm{O}$ mundo de Belshazar, depois de sua representação elegíaca, será destruído pelos persas, não sem a traição decisiva da figura da intolerância neste contexto - um sacerdote de um outro templo, ressentido com a hegemonia de Ishtar.

Ao caracterizar estes empenhos políticos do cineasta tal como eles se expõem na própria lógica interna de sua obra, tenho me apoiado numa historiografia americana que, de modo geral, têm sido muito mais dura na leitura de Griffith do que os europeus, onde prevalece um tom de respeito mais distante ao pioneiro, categoria que promove uma espécie de estetização do que há de paterno na figura do cineasta, dado que ressaltei na leitura do filme dos Taviani. De um lado e de outro do Atlântico, o traço comum das leituras é a presença marcante de tais veleidades patriarcais, com a diferença de que o que se ameniza no perfil de cavalheiro, ao estilo de Bom dia Babilônia, ganha conotações mais repressivas na observação historicamente mais precisa feita nos Estados Unidos nos últimos anos. Posta esta diferença 
de ênfase, vejamos seus desdobramentos na questão da paz e da guerra.

Na configuração dos quatro tempos de sua arquitetura, Intolerância estabelece uma progressão que está longe de ser acidental. O tempo chave, organizador da história humana, é o da Paixão de Cristo, que divide a história em duas épocas - o caminho da deriva depois da queda e o caminho da salvação depois do sacrifício do Filho de Deus encarnado. O tempo da Babilônia é uma etapa no percurso da deriva, antes de Cristo, em que a cultura do Oriente viu a dissolução de suas melhores conquistas, e a notável cidade-Estado expõe, no filme, o paradigma das glórias efêmeras, das conquistas humanas perecíveis sem a luz da salvação. O século XVI francês é o tempo de um cristianismo desgarrado, adulterado, numa Europa que se afastou da Luz e se corrompeu, dirigindo sua agressão aos autênticos cristãos que, diante da degeneração dos portadores da mensagem do Salvador, lutaram por reformas, foram perseguidos e terminaram por se despedir do Velho Mundo decaído para recuperar o caminho da salvação no Novo Mundo, o qual observaram como terra virgem, desabitada, nos termos da promessa que a doutrina fundadora da nação transformou em Destino Manifesto, a ideologia da expansão e do imperialismo. O episódio moderno é o tempo de encaminhamento deste sonho americano.

$\mathrm{Na}$ cronologia das eras, o filme se move de Oriente para Ocidente, como se supõem terem se sucedido os impérios. Tal progressão é um dos aspectos de uma teleologia da salvação que desemboca nos Estados Unidos, lugar da reposição da história no verdadeiro caminho, mas também lugar em que ainda se manifestam as figuras da intolerância, com a diferença de que as condições no Novo Mundo permitem que se possa superar o destino de sacrifício que se reservou, nas outras épocas, aos inocentes. Neste caminhar do Oriente para o Ocidente, o paradigma das épocas assinala o conflito recorrente, o Bem e Mal, e apresenta as figuras que se complementam no cumprimento dos papéis decisivos, de um lado e de outro. Entretanto, o suceder das épocas mostra também um movimento de mudança que se faz visível na vida material e, para coroar este senso de que há uma teleologia na história, o século XX dá a ver o momento em que, no Novo Mundo, surge a promessa de cumplicidade pela qual os recursos técnicos à disposição da sociedade podem atuar na direção do Bem e resolver os problemas, constituindo uma paz duradoura. Isto já se assinala na disposição do enredo, feito de arrependimentos antes não existentes, de mobilização de um domínio do espaço pela técnica que altera substancialmente as condições de exercício das operações de resgate (alegoria de uma salvação no plano maior), dado que se reflete no seu desenlace que contrasta com o das outras épocas. No entanto, a dimensão teleológica se assinala de forma mais nítida no próprio terreno do cinema. Primeiro, porque como técnica de reprodução, grafia, ele traz a chance de uma linguagem visual de cunho universal, numa promessa que, presente na Babilônia, foi destruída, só retornando agora nesta nova arte que tem, neste sentido, uma conotação messiânica logo na origem ${ }^{8}$. Segundo, porque, assumida esta dimensão, é no trabalho do próprio Griffith que esta promessa melhor se realiza, numa confirmação da hipótese do papel
${ }^{8}$ Ver Miriam Hansen, op. cit., pp. 173-198. 
condutor da nação constituída no Novo Mundo.

O último ponto é fundamental, e Griffith o configurou com cuidado. Tal como os Taviani narraram em seu filme, um primeiro aspecto foi a resposta a Cabiria. E o episódio da Babilônia fêz-se o emblema da afirmação de uma hegemonia. A representação da Noite de São Bartolomeu dialoga, na mesma tônica de superação, com a tradição dos Films D'Art, orgulho de certas tendências do cinema francês. A Paixão de Cristo retoma um dos temas mais célebres e bastante reiterados no cinema do início do século. Na estória moderna, Griffith desenvolve aquilo que se identifica como o seu estilo por excelência, avançando na construção da narrativa clássica na linha do que começara a fazer na Biograph. Na arquitetura geral de sua composição, ousa um tipo de montagem que procura dar expressão aos esquemas tipológicos de interpretação da história próprios ao cristianismo. $\mathrm{E}$ desafia os espectadores com um espetáculo cuja montagem, em termos do que é específico ao cinema, se mostra mais grandiosa do que o prodígio arquitetônico do cenário da Babilônia. Enfim constrói um monumento, alegoria da história que coloca seu cinema como um coroamento e uma reposição de promessas antigas, colocando a nação de que narrou o nascimento no centro de uma nova era da humanidade.

Configura-se um esquema messiânico nacional a que, de resto, não falta aquele aspecto em que a alegoria expõe a sua conotação de advertência, como observarei a seguir.

Num discurso paralelo à elegia dos Taviani pode-se, portanto, desenhar um outro enredo nas relações do cineasta com o plano mais agressivo das lutas históricas, não sendo preciso apelar para $O$ nascimento de uma nação para que se configurem as batalhas concretas que seu cinema assumia, pois Intolerância, de forma mais alegórica, porém não menos empenhada, estava lá envolvido nas batalhas de sua sociedade, de modo que a natureza do seu projeto (e do cinema) nos escapa se atentarmos apenas para o plano mais nobre e universal das grandes arquiteturas, onde está presente, sem dúvida, o diálogo com investimentos estéticos do passado que o Griffith personagem dos Taviani expõe no banquete de casamento. Ao buscar o avesso da visão sublimada trazida por Bom dia Babilonia o objetivo não é propriamente discutir a envergadura estética do projeto griffithiano de uma arte de massas, mas mostrar a articulação deste lado da história com a implicação política dos valores.

Tais implicações estão lá, em Intolerância, embora seu enredo se concentre no movimento da consciência que se arrepende, sem propriamente tranformar em heróis os agentes da ação punitiva, restauradora da ordem. O caráter exemplar da estória narrada tem como horizonte a afirmação de uma esperança, a presença de uma providencial vocação à felicidade apoiada no que de mais específico a sociedade americana apresenta, em contraposição aos tempos desafortunados que o paralelismo da montagem evoca. Há, como observei, o movimento de uma consciência, mas este só se torna efetivo porque existe um ritual de justiça a ensejar o intervalo certo para que a sociedade mobilize a técnica moderna e repare seus erros antes que seja tarde. A trama que leva ao desfecho é intrincada, envolve várias personagens que funcionam como reparadores de 
ocasião, à exceção da própria esposa do herói que acompanha os esforços de uma autoridade diligente e exerce a sua influência de mulher vitimada toda vez que o sentimento é o fator decisivo que move os homens do poder ${ }^{9}$.

Curiosamente, dentro do campo desta discussão, o ponto em que Intolerância define melhor a "lição da história" como advertência de eterna vigilância é o episódio da Babilônia, instância maior do erro irreparável. Belshazar vive a paz e o amor sem se preparar para a guerra. E paga o alto preço da morte e da destruição de seus valores, estes de que Griffith compõe a elegia, ao mesmo tempo ressaltando a sua cegueira diante das ameaças, uma certa embriagues que, embora alimentada de bons sentimentos, define aí o excesso criticável em que o princípio do amor resvalaria para um hedonismo fatalmente insensível ao princípio de realidade ("se queres a paz, prepara-te para a guerra").

Guardadas as proporções, há um jogo de espelhos pelo qual a Hollywood-Babilônia dos Irmãos Taviani, e Griffith dentro dela, são colocados numa posição, nas vésperas da Primeira Guerra, que faz ecoar o que o cineasta americano, em sua configuração da história, definiu para a Babilônia, lugar de uma experiência idílica cujas promessas foram truncadas por uma violência vinda de fora (a invasão de Ciro lá, a guerra mundial aqui). Deste modo, se os Taviani monumentalizam a figura do cineasta, lhe oferecendo a imagem desejada, estão em verdade lhe devolvendo algo do que ele mesmo projetou em Belshazar. É claro que não o fizeram no mesmo tom nem com a mesma unidimensionalidade, mas na exata medida em que efetivamente fizeram prevalecer, como observei, a separação radical entre os empenhos do artista (à imagem de Belshazar) e a esfera dos conflitos sociais e da guerra (à imagem da invasão de Ciro), colocando no centro de sua parábola sobre a nova arte a imagem do nobre pacifista. A ironia, no caso, é que o cineasta estava empenhado não apenas em sua elegia aos monumentos e à cultura da Babilônia, mas também na advertência que supunha, neste episódio específico, a desatenção como um "erro fatal" de Belshazar, ingenuidade que não caberia repetir como bem reiteraram seus outros filmes e toda uma tradição de Hollywood voltada para a questão nacional dentro desta moldura defensiva ${ }^{10}$.

No caso dos Taviani, se há em sua alegoria a dimensão de advertência, esta se imprime nas palavras do pai ao vaticinar a união como condição do sucesso dos irmãos, palavras que poderiam, em outro torneio alegórico, ser entendidas como alusão ao desastre europeu que propiciou uma das condições chave da hegemonia americana: a ruptura com o concerto universal das artes instituída pela guerra, esta mesma que se toma como responsável pela origem da efetiva hegemonia americana na cultura de massas do século, uma hegemonia que Griffith já proclamava em 1916. Nesta direção, os Taviani estariam selando, ao mesmo tempo, o comentário histórico e a reafirmação do principio de unidade como condição da eficácia, no plano do seu próprio trabalho em família e no plano mais geral da luta política, como era do gosto de certa esquerda. Tal princípio não deixava, em 1987, de acenar para a questão do próprio cinema e a necessidade de um concerto das nações da Europa para um renascimento que, entre outras coisas, evitasse que os cineastas fossem para Hollywood ou
${ }^{9} 0$ aspecto paternal do gesto de clemência do governador, ao reconhecer diante da confissão de uma mulher em prantos a inocência do protagonista, remete ao gesto de Lincoln, o pai maior, em 0 nascimento, quando sua assinatura salva a vida do herói induzido pelas lágrimas de uma mãe em desespero.

${ }^{10}$ John Ford, como discípulo maior de Griffith, vai desenvolver de forma explícita esta idéia de uma ordem institucional humanista que, no entanto, estará toda apoiada nas figuras que, a custo mesmo da traição de premissas democráticas, garantem sua defesa diante de inimigos sempre à espreita. A oposição entre civilização e barbárie, no western, terá arranjos mais sutis do que o encontrado em Griffith, e Ford marcará sua maestria na cunhagem de heróis de feição trágica cuja truculência, praticada no limite da desmedida mas para bem da ordem, estará articulada a uma condição de impasse, a um "sem destino" que poderá se traduzir no reiterado exílio ou no esquecimento, como em Rastros de ódio (1956) e 0 homem que matou o facínora (1962). Retirá-las, simbolica-mente, de tal condição é um dos efeitos da alegoria de advertência. 
capitulassem diante de seu imaginário.

O problema é que, ressalvada a originalidade de estilo dos extraordinários autores de Padre Padrone, esse imaginário ecoa com intensidade no próprio Bom dia Babilônia, alimentado pelo tom elegíaco de sua recordação das matrizes de Hollywood. Tudo começa com uma evocação da Babilônia que se anuncia irônica, pois o título do filme ressoa num contexto em que a associação entre os aspectos hedonistas da cultura industrializada, a idéia de pecado (assumida com bom humor e irreverência) e as fofocas em torno da vida mundana das estrelas já haviam constituído um estereótipo que inspirou, por exemplo, o título do livro de Kennett Anger, HollywoodBabylon, publicado em 1960. Tais conotações não são recusadas pelo filme, no que este tem de projetivo na saudação a uma hegemonia hollywoodiana localizada no pósPrimeira Guerra. Mas seu empenho maior está na evocação do que miticamente certa historiografia configurou como uma idade da inocência anterior a tal imperialismo da imagem, momento em que o concerto dos criadores, numa ponte Itália-Estados Unidos, supostamente teria expressado a afinidade da grande arquitetura e do grande cinema, celebrados na cena do banquete, clássica ocasião para discussões estéticas temperadas por nobres emulações.

Sob a égide de um princípio de continuidade, termina por prevalecer, em Bom dia Babilônia, a monumentlização da arte como expressão do "sonho coletivo", ao lado de um certo senso melancólico de comunidades que o mundo moderno, de fato, já não comportava em 1915, momento em que já se afigurava com nitidez o compromisso entre cinema, guerra e projetos nacionais de supremacia que pautaram a violência do século.

\section{Abstract}

This text focuses the allegories relationsship between cinema, architecture, religion, art, family, Europe and Griffith's Intolerance. The confrontations occur, in unforgettable chenging plans, in which the two paternal figures tell their stories and what we can expect from them.

Keywords: cinema, Babilônia, allegories, Grffith, Tavianis.

Data do recebimento: 23/09/2008

Data do aceite: 12/11/2008 